\title{
SUB-ACUTE TOXICITY STUDY OF ETHANOLIC EXTRACT OF PACING (COSTUS SPECIOSUS) IN MALE MICE
}

\section{IKA PUSPITA SARI, ARIEF NURROCHMAD}

\author{
Department of Pharmacology and Clinical Pharmacy, Faculty of Pharmacy, Universitas Gadjah Mada, 55281, Yogyakarta, Indonesia \\ Email: ika.puspitasari@gmail.com
}

Received: 18 Aug 2016 Revised and Accepted: 05 Oct 2016

\section{ABSTRACT}

Objective: The aim of this research was to evaluate the safety of Costus speciosus extract (CSE) after a 90-day administration in male mice.

Methods: Sub-acute toxicity test was performed using the OECD 408 method. CSE at 275-1100 mg/kg/day was administered to male mice for $90 \mathrm{~d}$. The appearance of toxic symptoms was observed every day, followed by measurement of food and drink intakes. Change in body weight, the result of a routine blood check and blood biochemistry were observed and statistical analysis was performed on them. Test animals were killed at the end of the study and the weights of vital organs were examined before organ histology was examined.

Results: The research result showed that the administration of CSE at $275-1100 \mathrm{mg} / \mathrm{kg} / \mathrm{day}$ for $90 \mathrm{~d}$ did not show any significant disturbance in all parameters, except for reductions of cholesterol and blood glucose levels of test animals $(\mathrm{p}<0.05)$.

Conclusion: The results obtained in this research indicated the safety of CSE as a candidate of standardized herbal medicine for male contraception.

Keywords: Costus speciosus, Sub-acute toxicity, Safety

(C) 2016 The Authors. Published by Innovare Academic Sciences Pvt Ltd. This is an open access article under the CC BY license (http://creativecommons.org/licenses/by/4. 0/)

DOI: http://dx.doi.org/10.22159/ijpps.2016v8i12.14765

\section{INTRODUCTION}

Pacing (Costus speciosus) in India is used as a traditional medicine for various diseases, e. g. as anti-diabetic and anti-infective medicines. In Indonesia, Pacing thrives in wet areas without care. Pacing is known as a wild plant belongs to family Costaceae, although lately it is cultivated as a decorative plant. In Java, Pacing which grows wild in yards or riverbanks has not been utilized. Meanwhile, in Wawoni Island in Sulawesi, Pacing has been used as a traditional medicine to reduce fertility in men and women for a long time. The part of Pacing which is usually used is the tuber [1].

Costus speciosus is a succulent, perennial rhizomatous herb with erect or spreading stems. Leaves are smooth and spirally arranged around the trunk. The leaves are dark green in colour, elliptic or obovate in shape. The flowers are white and fragrant and look like crepe paper. Fruit is red in colour whereas seeds are black [2]. The rhizome extract has exhibited antibacterial, antifungal, anticholinesterase, antioxidant, anti-inflammatory, antipyretic, antihyperglycemic, antistress, larvicidal, diuretic, as well as estrogenic properties [3]. The rhizome of Costus speciosus is a good source of saponin-like diosgenin, sapogenin, tigogenin, steroids, diosgenin, $5 \alpha$-stigmast-9(11)-en-3 $\beta$-ol, sitosterol- $\beta$-D-glucoside, dioscin, pro sapogenins $\mathrm{A}$ and $\mathrm{B}$ of dioscin, gracillin, quinines, $\alpha$ tocopherol, triacontanoic acids, curcumin, triacontanol, $\alpha$-amyrin stearate, $\beta$-amyrin, and lupeol. Low levels of diosgenin and phenolic compounds are also found in the leaves and flower [2].

Costus speciosus exhibited an anti-fertility effect in male mice through a significant reduction in both spermatozoa level and quality [4]. This is the preclinical efficacy proof of traditionallypracticed uses of costus aqueous extract in the community. In Indonesia, the growth of the herbal industry is strongly supported by the government. The Indonesian government forces the herbal industry to determine the safety of herbal product applying OECD guidelines for sub-acute toxicity method 408 [5] when herbal medicine is released to the market as a standardized herbal medicine. It is possible that in the future there will be a standardized herbal anti-fertility medicine for man, supporting family planning programs in Indonesia. The aim of this study was, therefore, to determine the safety of Costus speciosus ethanol extract (CSE) in male mice during $90 \mathrm{~d}$ oral administration.

\section{MATERIALS AND METHODS}

\section{Plant material}

The plant of Costus speciosus was collected from the Sleman district (Latitude $7^{\circ} 42^{\prime} 58.19^{\prime \prime S}$, Longitude $110^{\circ} 20^{\prime} 7.45^{\prime \prime E}$, Altitude 192.96 $\mathrm{m}$ ) around March. The plant was identified and authenticated by an expert in botany Djoko Santosa, MSc, Department of Biology Pharmacy, Faculty of Pharmacy, Universitas Gadjah Mada, Yogyakarta, Indonesia.

\section{Preparation of standardized Costus speciosus extracts (CSE)}

The collected stem, leaves, and flower were shade-dried and powdered in a mixer-grinder (Philips) to get a coarse powder. The powdered plant material $(5000 \mathrm{~g})$ was extracted with $50 \%$ ethanol by using maceration apparatus (Rekayasa Wangdi). The aqueous extract was evaporated to obtain a viscous dark green extract (yield $=10 \%$ ). CSE was analyzed as a standardized extract following Indonesian Herbal Pharmacope. There were no contaminants of arsenic (As), cadmium (Cd), mercury (Hg) and plumbum (Pb) and no bacterial and fungus contaminants (Escherichia coli, Pseudomonas aeruginosa, Salmonella typhi, Staphylococcus aureus and Candida albicans); diosgenin level was $0.03 \%$ and phenolic compound $2.20 \%$.

\section{Treatment of animals}

Fifty adult male mice weighing 20-25 g were used in the present study. Animals were housed in standard mouse cages, maintained under standard conditions (12-h light/dark cycle; $25 \pm 3{ }^{\circ} \mathrm{C}$ temperature; $70-80$ relative humidity), and provided a standard laboratory chow and water ad libitum. Drug or vehicle was administered to all animals by oral intubation.

\section{Dose and duration of treatment}

Male mice were divided into 5 groups of 10 mice each. The daily dose of CSE was freshly dissolved in $0.1 \mathrm{ml}$ of sodium CMC $0.5 \%$ (Brataco) and orally administered to each experimental animal every morning for $90 \mathrm{~d}$. 
Group A control mice received $0.1 \mathrm{ml}$ of the vehicle sodium CMC $0.5 \%$.

Group B mice were treated with CSE at $275 \mathrm{mg} / \mathrm{kg} /$ day

Group C mice were treated with CSE at $550 \mathrm{mg} / \mathrm{kg} /$ day

Group D mice were treated with CSE at $1100 \mathrm{mg} / \mathrm{kg} /$ day

Group E recovery of $105 \mathrm{~d}$ after treatment from Group D (satellite group)

Initial and final body weights of the animals were recorded.

\section{Histopathological examination}

The animals were weighed and autopsied under light anesthesia $24 \mathrm{~h}$ after the last dose of the treatment. The animals were dissected and various organs of the reproductive tract namely testes, epididymis and seminal vesicle along with some vital organs such as liver, heart, and kidney were excised, cleared of adhering fat and connective tissue and weighed. Samples of liver and kidney were fixed in 10\% neutral buffered formalin (Brataco), embedded in paraffin (Brataco), sectioned at $5 \mu \mathrm{m}$, and stained with hematoxylin (Sigma-Aldrich) and eosin (Sigma-Aldrich), following the standard laboratory procedures. The stained sections were examined under a microscope (Olympus) for any change in morphology.

\section{Hematological studies}

Blood was collected and analyzed for red blood cell count (RBC) and white blood cell count (WBC), hemoglobin count $(\mathrm{Hb})$, packed cell volume (PCV), mean corpuscular volume (MCV), mean corpuscular hemoglobin count (MCH), mean corpuscular hemoglobin concentration (MCHC),blood sugar, blood cholesterol, blood urea, blood creatinine, as well as aspartate aminotransferase (AST) and alanine transaminase (ALT) by standard methods.

\section{Ethical aspects}

The study was approved by an ethical committee of the Animal Ethics, Integrated Laboratory, Universitas Gadjah Mada (UGM), Yogyakarta, Indonesia, whose standards for maintenance and use of the experimental animals were followed.

\section{Statistical analysis}

Data are expressed as mean \pm SEM. One-way ANOVA and Student's ttest were used for statistical comparison. All values of $p<0.05$ were considered as significantly different.

\section{RESULTS}

\section{Effect of CSE on general appearance and behavioral observation}

The sub-acute toxicity study of the tested extract was determined as per OECD guideline 408 [5]. All the tested group animals treated with CSE extract at doses 275,550 and $1100 \mathrm{mg} / \mathrm{kg}$ daily survived throughout the $90 \mathrm{~d}$. No clinical toxicity signs were observed in the extract treated group compared to the control group.

\section{Effect of CSE on relative organ body weight}

There was no significant difference in average organ weight between control and CSE groups at doses 275,550 and $1100 \mathrm{mg} / \mathrm{kg}$. The results revealed that the vital organs such as liver, heart, and kidney were not adversely affected throughout the treatment by CSE $(\mathrm{P}>0.05)$.

Table 1: General appearance and behavioral observation of sub-acute toxicity study for control and treated groups

\begin{tabular}{|c|c|c|c|c|c|}
\hline Observations & Control group & $275 \mathrm{mg} / \mathrm{kg} / \mathrm{d}$ & $550 \mathrm{mg} / \mathrm{kg} / \mathrm{d}$ & $1100 \mathrm{mg} / \mathrm{kg} / \mathrm{d}$ & Satellite group \\
\hline Body weight & normal & normal & normal & normal & normal \\
\hline Temperature & normal & normal & normal & normal & normal \\
\hline Food intake & normal & normal & normal & normal & normal \\
\hline Urination & normal & normal & normal & normal & normal \\
\hline Change in skin & No effect & No effect & No effect & No effect & No effect \\
\hline Drowsiness & No effect & No effect & No effect & No effect & No effect \\
\hline Sedation & No effect & No effect & No effect & No effect & No effect \\
\hline Eye color & No effect & No effect & No effect & No effect & No effect \\
\hline Diarrhea & Not present & Not present & Not present & Not present & Not present \\
\hline Death & Alive & Alive & Alive & Alive & Alive \\
\hline
\end{tabular}

Table 2: Effect of CSE treatment on the body and reproductive organ weight measurements of male mice

\begin{tabular}{|c|c|c|c|c|c|}
\hline \multirow[t]{2}{*}{ Treatment } & \multicolumn{2}{|c|}{ Body weight (g) } & \multicolumn{3}{|c|}{ Reproductive organs weight (mg/10 g body weight) } \\
\hline & Initial & Final & Testes & Epididymis & Seminal vesicle \\
\hline Group A, control (vehicle treated) & $21.00 \pm 0.42$ & $29.00 \pm 0.60$ & $245.05 \pm 20.65$ & $98.52 \pm 9.95$ & $221.05 \pm 15.03$ \\
\hline Group B, $275 \mathrm{mg} / \mathrm{kg} / \mathrm{d}$ for $90 \mathrm{~d}$ & $20.50 \pm 0.30$ & $29.82 \pm 0.05$ & $251.02 \pm 15.20$ & $101.02 \pm 8.90$ & $225.12 \pm 18.10$ \\
\hline Group B, $550 \mathrm{mg} / \mathrm{kg} / \mathrm{d}$ for $90 \mathrm{~d}$ & $22.00 \pm 0.02$ & $30.01 \pm 0.25$ & $249.08 \pm 18.22$ & $100.50 \pm 5.56$ & $224.20 \pm 20.10$ \\
\hline Group B, $1100 \mathrm{mg} / \mathrm{kg} / \mathrm{d}$ for $90 \mathrm{~d}$ & $21.52 \pm 0.21$ & $29.72 \pm 0.12$ & $246.50 \pm 20.12$ & $98.12 \pm 10.20$ & $228.10 \pm 8.90$ \\
\hline Group B, recovery withdrawal of $105 \mathrm{~d}$ & $22.14 \pm 0.15$ & $29.70 \pm 0.24$ & $248.80 \pm 22.30$ & $98.34 \pm 11.15$ & $225.56 \pm 9.78$ \\
\hline
\end{tabular}

Values are expressed as mean \pm SEM. $>>0.05$, when compared to control group (One-way ANOVA followed by Student's t-test).

Table 3: Effect of CSE treatment on the organ weight measurements of male mice

\begin{tabular}{|c|c|c|c|}
\hline \multirow[t]{2}{*}{ Treatment } & \multicolumn{3}{|c|}{ Organ weight } \\
\hline & Liver & Heart & Kidney \\
\hline Group A, control (vehicle treated) & $0.88 \pm 0.03$ & $0.16 \pm 0.02$ & $0.35 \pm 0.02$ \\
\hline Group B, $275 \mathrm{mg} / \mathrm{kg} / \mathrm{d}$ for $90 \mathrm{~d}$ & $0.87 \pm 0.01$ & $0.17 \pm 0.01$ & $0.34 \pm 0.03$ \\
\hline Group B, $550 \mathrm{mg} / \mathrm{kg} / \mathrm{d}$ for $90 \mathrm{~d}$ & $0.84 \pm 0.02$ & $0.15 \pm 0.02$ & $0.34 \pm 0.02$ \\
\hline Group B, $1100 \mathrm{mg} / \mathrm{kg} / \mathrm{d}$ for $90 \mathrm{~d}$ & $0.86 \pm 0.01$ & $0.16 \pm 0.01$ & $0.36 \pm 0.03$ \\
\hline Group B, recovery withdrawal of $105 \mathrm{~d}$ & $0.87 \pm 0.02$ & $0.16 \pm 0.01$ & $0.34 \pm 0.04$ \\
\hline
\end{tabular}

Values are expressed as mean \pm SEM. $P>0.05$, when compared to control group (One-way ANOVA followed by Student’s t-test).

\section{Effect of CSE on hematological parameters}

All the tested hematological parameters including RBC, WBC, Hb, $\mathrm{PCV}, \mathrm{MCV}, \mathrm{MCH}, \mathrm{MCHC}$, platelet and neutrophil counts were within normal values compared to the control group. Generally, there were no significant differences noted between control and treated groups for the hematological parameter measured (table 4). 
Table 4: Effect of CSE treatment on the hematological parameters of male mice

\begin{tabular}{|c|c|c|c|c|c|c|c|c|c|}
\hline Treatment & $\begin{array}{l}\text { RBC } \\
\left(\mathrm{x} 10^{6} / \mu \mathrm{l}\right) \\
\end{array}$ & $\begin{array}{l}\text { WBC } \\
\left({\left.\mathrm{X} 10^{3} / \mu \mathrm{l}\right)}\right.\end{array}$ & $\mathrm{Hb}(\mathrm{g} / \mathrm{dl})$ & $\begin{array}{l}\text { PCV } \\
(1 / 1) \\
\end{array}$ & $\begin{array}{l}\text { MCV } \\
\text { (fl) }\end{array}$ & $\begin{array}{l}\text { MCH } \\
\text { (pg) }\end{array}$ & $\begin{array}{l}\text { MCHC } \\
\text { (g/dl) }\end{array}$ & $\begin{array}{l}\text { Platelet count } \\
\left(\mathrm{X} 10^{3} / \mu \mathrm{l}\right)\end{array}$ & $\begin{array}{l}\text { Neutrophil } \\
(\%)\end{array}$ \\
\hline $\begin{array}{l}\text { Group A, } \\
\text { control } \\
\text { (vehicle } \\
\text { treated) }\end{array}$ & $8.03 \pm 0.56$ & $6.50 \pm 0.42$ & $13.30 \pm 0.05$ & $39.50 \pm 1.20$ & $42.30 \pm 1.05$ & $12.10 \pm 0.85$ & $32.00 \pm 3.00$ & $302.10 \pm 11.00$ & $25.20 \pm 1.50$ \\
\hline $\begin{array}{l}\text { Group B, } 275 \\
\mathrm{mg} / \mathrm{kg} / \mathrm{d} \text { for } \\
90 \mathrm{~d}\end{array}$ & $8.00 \pm 0.72$ & $6.62 \pm 0.61$ & $12.98 \pm 0.04$ & $40.00 \pm 2.30$ & $40.50 \pm 1.00$ & $11.90 \pm 0.55$ & $32.10 \pm 2.80$ & $301.20 \pm 10.80$ & $22.80 \pm 2.00$ \\
\hline $\begin{array}{l}\text { Group B, } 550 \\
\mathrm{mg} / \mathrm{kg} / \mathrm{d} \text { for } \\
90 \mathrm{~d}\end{array}$ & $7.94 \pm 0.12$ & $7.01 \pm 0.02$ & $12.80 \pm 0.07$ & $39.80 \pm 3.20$ & $39.80 \pm 1.50$ & $12.00 \pm 0.50$ & $31.50 \pm 3.85$ & $309.00 \pm 9.90$ & $23.90 \pm 2.50$ \\
\hline $\begin{array}{l}\text { Group B, } 1100 \\
\mathrm{mg} / \mathrm{kg} / \mathrm{d} \text { for } \\
90 \mathrm{~d}\end{array}$ & $8.14 \pm 0.66$ & $6.88 \pm 0.04$ & $11.88 \pm 0.08$ & $38.90 \pm 1.10$ & $41.80 \pm 0.60$ & $12.70 \pm 0.60$ & $32.20 \pm 1.50$ & $304.70 \pm 7.85$ & $23.10 \pm 2.05$ \\
\hline $\begin{array}{l}\text { Group B, } \\
\text { recovery } \\
\text { withdrawal of } \\
105 d\end{array}$ & $7.96 \pm 0.11$ & $6.45 \pm 0.22$ & $12.58 \pm 0.15$ & $40.00 \pm 3.10$ & $40.00 \pm 1.20$ & $12.00 \pm 0.75$ & $32.00 \pm 2.25$ & $304.00 \pm 6.90$ & $22.90 \pm 2.80$ \\
\hline
\end{tabular}

Values are expressed as mean \pm SEM. P $>0.05$, when compared to control group (One-way ANOVA followed by Student's t-test), RBC (red blood cell count). WBC (white blood cell count), Hb (hemoglobin count), PCV (packed cell volume), MCV (mean corpuscular volume), MCH (mean corpuscular hemoglobin count), MCHC (mean corpuscular hemoglobin concentration).

\section{Effect of CSE on biochemical parameters}

The results of the various biochemical tests on the treated animals are summarized in table 6. Oral administration of CSE at a doses 275, 550 and $1100 \mathrm{mg} / \mathrm{kg}$ did not cause a significant change in AST, ALT, blood creatinine and blood urea when compared to the control group. There were significant reductions of cholesterol levels after CSE doses $275-1100 \mathrm{mg} / \mathrm{kg}(15-20 \%$; R 0.05$)$. The reduction of blood glucose levels occurred after CSE administration 550-1100 $\mathrm{mg} / \mathrm{kg}(\mathrm{P} \leq 0.05)$.

Table 5: Effect of CSE treatment on the biochemistry parameters of male mice

\begin{tabular}{|c|c|c|c|c|c|c|}
\hline Treatment & $\begin{array}{l}\text { Blood sugar } \\
(\mathrm{mg} / \mathrm{dl})\end{array}$ & AST (U/l) & ALT (U/I) & $\begin{array}{l}\text { Blood creatinin } \\
(\mathrm{mg} / \mathrm{dl})\end{array}$ & $\begin{array}{l}\text { Blood urea } \\
(\mathrm{mg} / \mathrm{dl})\end{array}$ & $\begin{array}{l}\text { Total cholesterol } \\
\text { (mg/dl) }\end{array}$ \\
\hline $\begin{array}{l}\text { Group A, control (vehicle } \\
\text { treated) }\end{array}$ & $145.90 \pm 1.20$ & $116.40 \pm 10.00$ & $37.50 \pm 0.62$ & $1.05 \pm 0.02$ & $35.30 \pm 0.08$ & $106.00 \pm 5.50$ \\
\hline $\begin{array}{l}\text { Group B, } 275 \mathrm{mg} / \mathrm{kg} / \mathrm{d} \text { for } \\
90 \mathrm{~d}\end{array}$ & $128.56 \pm 4.10^{*}$ & $116.45 \pm 12.00$ & $37.00 \pm 0.52$ & $1.06 \pm 0.03$ & $35.00 \pm 0.02$ & $86.00 \pm 4.20^{*}$ \\
\hline $\begin{array}{l}\text { Group B, } 550 \mathrm{mg} / \mathrm{kg} / \mathrm{d} \text { for } \\
90 \mathrm{~d}\end{array}$ & $122.42 \pm 3.80^{*}$ & $116.20 \pm 13.20$ & $36.50 \pm 0.22$ & $1.04 \pm 0.05$ & $34.55 \pm 0.04$ & $79.50 \pm 3.50 *$ \\
\hline $\begin{array}{l}\text { Group B, } 1100 \mathrm{mg} / \mathrm{kg} / \mathrm{dfor} \\
90 \mathrm{~d}\end{array}$ & $126.70 \pm 7.20^{*}$ & $115.58 \pm 11.40$ & $37.20 \pm 0.32$ & $1.04 \pm 0.07$ & $33.88 \pm 0.05$ & $76.00 \pm 8.40^{*}$ \\
\hline $\begin{array}{l}\text { Group B, recovery } \\
\text { withdrawal of } 105 \mathrm{~d}\end{array}$ & $144.98 \pm 2.50$ & $116.00 \pm 12.80$ & $37.05 \pm 0.09$ & $1.05 \pm 0.05$ & $34.70 \pm 0.09$ & $107.50 \pm 11.00$ \\
\hline
\end{tabular}

Values are expressed as mean \pm SEM. ${ }^{*} \mathrm{P} \leq 0.05$, when compared to control group (One-way ANOVA followed by Student's t-test).

\section{Histopathological studies}

Histological examination revealed that there were no changes observed due to the 90-day CSE administration in liver, heart, and the kidneys.

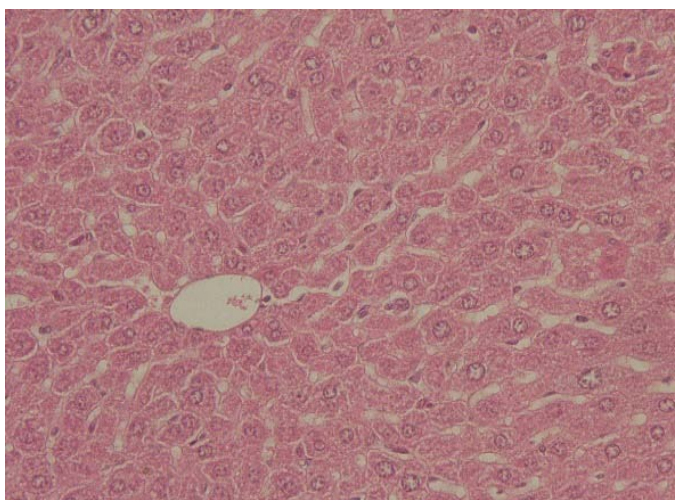

A

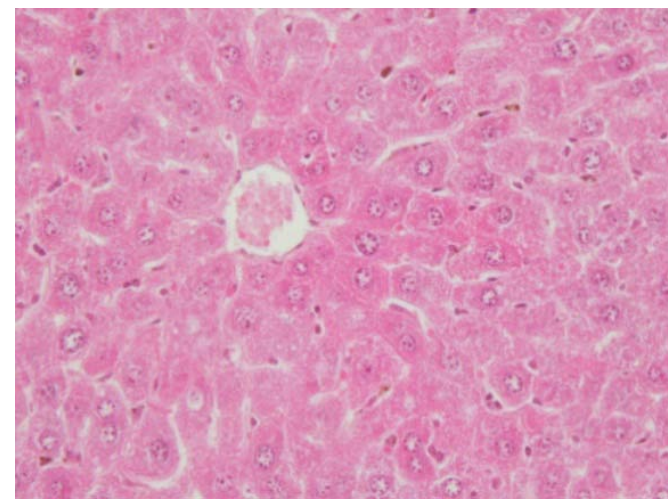



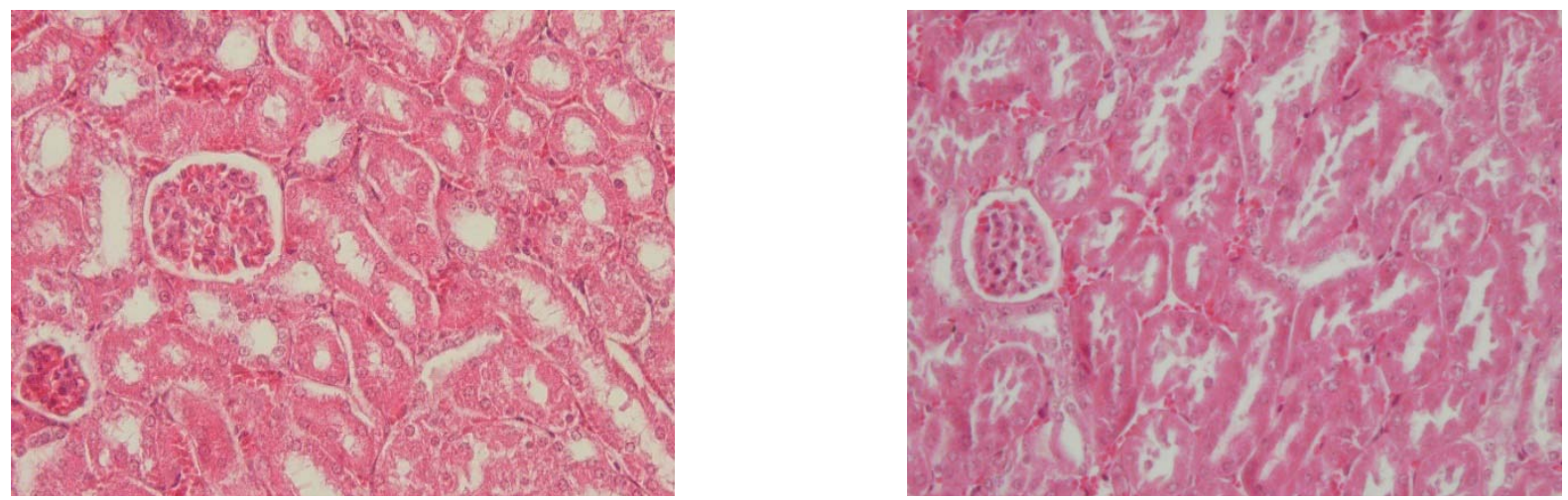

Fig. 1: Cross section of A. normal B. CSE $1100 \mathrm{mg} / \mathrm{kg} / \mathrm{d}$ treated mouse liver and kidney (staining with HandE)

\section{DISCUSSION}

The usage of herbal medicine in countries such as Indonesia is always considered safe as herbal medicine methods have been taught for generations for hundreds of years. The abundance of herbal resources, including costus, in Indonesia, leads to its usage as an herbal medicine. In the beginning, costus is known as an antifertility medicine in the traditional community in Wawoni Island, Sulawesi [1]. A previous study shows that costus is effective as an antifertility medicine in male animals and its usage does not cause any disturbance in the sexual performance of male test animals. This gives hope for the possibility of using costus as a standardized herbal contraceptive medication for men. The Indonesian government requires the production of standardized herbal medicines to ensure that preclinical tests are not only performed on the herbal pharmacological effect on test animals but also on the safety if later used on a human. Therefore, clinical evidence of the safety of the long-term usage of CSE should be performed by conducting sub-acute toxicity test for $90 \mathrm{~d}$. This is very normal since, based on previous studies, herbal medicines for male contraception are not entirely safe. Several researchers have studied gossypol as an efficient male contraception after testing it on animals and human [6]. Unfortunately, the usage of gossypol for male contraception in long terms also causes dangerous chronic effects so that the WHO researchers emphasize the importance of toxicity tests to ensure the safety of gossypol [7].

This toxicity test generally showed that the usage of CSE for $90 \mathrm{~d}$ did not cause any significantly toxic effect on behavioral parameters, changes in body weight, or changes in weights of vital organs and reproductive organs. Body weight loss or increase indicates the herb's toxic effects. Similarly, changes in weights of vital organs and reproductive organs show the herbal effect on the organs. In this study, repeated administration of CSE did not affect the physiology of body weight and organ weight. The administration of gossypol at $1 \mathrm{mg} / \mathrm{kg} /$ day for $130 \mathrm{~d}$ on dogs causes anorexia and loss of weight. Similar things happen to rabbits, which are administered gossypol at $80 \mathrm{mg} / \mathrm{kg} /$ day for 8-17 d [8]. Momordica charantia extract at the dose $50 \mathrm{mg}$ caused the suppression on both weight and volume of testes rats [9].

Blood and biochemical parameters also did not show any significant change, except for reduced cholesterol levels after administering any dosage of CSE. As in previous studies, CSE exposure up to 5000 $\mathrm{mg} / \mathrm{kg}$ did not cause any death on the test animals. The safety limit of CSE is possibly very high. This was proven by repeated CSE exposure at 275 to $1100 \mathrm{mg} / \mathrm{kg}$ for up to $90 \mathrm{~d}$, which did not cause any toxic effect in all clinical parameters on the male test animals. Reduced cholesterol after the administration of CSE was very likely due to the characteristics of compounds contained in CSE, including sitosterol, which can reduce cholesterol by a competitive inhibition mechanism with cholesterol absorption, which is shown by sitosterol [10]. Curcumin, which is also contained in CSE, is also known as a compound which can reduce cholesterol level by a mechanism which increases the transformation of cholesterol into bile acid by an increasing7a-hydroxylase enzyme (CYP7A1) [11].
Reduced blood glucose level happened after the administration of CSE at $550-1100 \mathrm{mg} / \mathrm{kg}$ for $90 \mathrm{~d}$. This is not surprising because CSE is known as an herbal medicine for the treatment of diabetes mellitus in India. A previous study also shows that ethanol extract of Costus speciosus rhizoma at 150 and 300 $\mathrm{mg} / \mathrm{kg}$, which is administered for $4 \mathrm{w}$, reduces blood glucose, cholesterol and triglyceride levels [12]. The compound in Costus speciosus that is suspected to reduce glucose and cholesterol levels is eremanthin [13].

Another plant which contains diosgenin is Dioscorea zingiberensis caused an increase in bilirubin in test animals when administered in the long term at $510 \mathrm{mg} / \mathrm{kg} /$ day [14]. Increased bilirubin level did not happen in the administration of CSE at $275-1100 \mathrm{mg} / \mathrm{kg} /$ day in the current study.

The histology of all organs did not show any change after the administration of CSE at $275-1100 \mathrm{mg} / \mathrm{kg} /$ day. This makes CSE perspective as a standardized herbal medicine for male contraception. Histological changes in vital organs should receive serious attention. Herbal medicines, which are administered as contraception, are expected not to affect vital organs, such as liver, heart, kidney, stomach and intestines. Gossypol, which used to be a candidate of contraceptive medicine, causes various histological disorders in several organs. When gossypol was administered at 1 $\mathrm{mg} / \mathrm{kg} /$ day for $130 \mathrm{~d}$ to dogs, death occurred, accompanied by myocarditis and endocarditis. If the dosage is increased to 3 $\mathrm{mg} / \mathrm{kg} /$ day, cardiac hypertrophy, congestion of kidney and spleen, fatty degeneration and liver necrosis will occur, exacerbated by edema and hemorrhage of the lungs [15]. The administration of Abrus precarious extract at $400-1600 \mathrm{mg} / \mathrm{kg} / \mathrm{day}$ for $18 \mathrm{~d}$ also leads to liver disorder, which is lymphocytic infiltration in vena portae [16]. Both gossypol and Abrus precatorius are candidates of male contraception. It is suspected that in Abrus precatorius, there is not only glycyrrhizin, which prevents spermatogenesis, but also ricin and abrin, which may be toxic to the liver [17].

The administration of CSE at $275-1100 \mathrm{mg} / \mathrm{kg}$ did not cause any changes in the testosterone, LH and FSH levels. It seems that the mechanism of CSE as an antifertility in males does not involve inhibition of male hormones. The mechanism of CSE as an antifertility is still unknown. It is possibly a spermatozoa motility interruption mechanism (table 4). Several plant extracts which have antifertility characteristics in males without involving hormonal mechanisms, such as Aegle marmelos, Juniperus phoenica and Quassia amara, reduce spermatozoa motility and increase spermatozoa abnormality $[17,18$, 19]. An antifertility compound may also be affected by the dosage, e. g. gossypol. Gossypol, which is administered at $7.5-15 \mathrm{mg} / \mathrm{kg} /$ day for 6$12 \mathrm{w}$, does not reduce testosterone, LH and FSH. Reduced testosterone, LH and FSH occur in mice, which are administered with gossypol at 20-30 mg/kg/day for 4-6 w [15]. Sitosterol compound in CSE may also contribute in the antifertility effect of CSE. Beta-sitosterol compound in methanol root extract of Barleria peritonitis caused suppression on sperm motility and density through the reduction on testosterone, LH and FSH levels in the male albino rats [20]. Some plant extracts exhibited antifertility characteristics in males with involving hormonal mechanisms such as Bupleurum sulphureum and Cichorium intybus [21]. 
Similar to the result of acute toxicity of CSE [4], no histological change was discovered in the tests of test animals which were administered with CSE at $275-1100 \mathrm{mg} / \mathrm{kg} /$ day for $90 \mathrm{~d}$. It showed the safety of CSE as a prospective herbal contraceptive medicine given in the medium term.

\section{CONCLUSION}

The research result showed that the safety of the usage of CSE for contraception should be observed, especially in relation to reduced blood glucose level, although other parameters did not show any significant disturbance.

\section{ACKNOWLEDGEMENT}

The authors are grateful to the State Ministry of Research and Technology for the financial support under the project number 814/UN1-P. III/IT/DIT-LIT/2016. The authors also thank Djoko Santosa MSc, for providing plant identification.

\section{CONFLICT OF INTERESTS}

The authors declare that there are no conflicts of interest.

\section{REFERENCES}

1. Rahayu M, Sunarti S, Sulistiarini D, Prawiroatmodjo S. Medicinal plants use in the local community of Wawonii island of South East. Biodiversity J 2006;7:245-50.

2. Van Steenis CGGJ. Flora for Indonesian student. Jakarta: Pradnya Paramita; 1987.

3. Pawar VA, Pawar PR. Costus speciosus: an important medicinal plant. Indian J Sci Res 2012;3:28-33.

4. Sari IP, Nurrochmad A, Rahayu S. Evaluation of antifertility effect of aqueous extract of Costus speciosus (Koen.) J. E. Smith rhizome in mice. Int J Pharm Chem Res 2016;8 Suppl 5:440-4.

5. The Organization for Economic Co-operation and Development (OECD). The OECD Guidelines for Testing of Chemicals: 408 Repeated Dose 90-Day Oral Toxicity Study in Rodents: OECD; 1998. p. 4.

6. Liu GZ, Lyle KC, Cao J. Clinical trial of gossypol as a male contraceptive drug. Part I. Efficacy study. Fertil Steril 1987;48:459-61.

7. Waites GM, Wang C, Griffin PD. Gossypol: reasons for its failure to be accepted as a safe, reversible male antifertility drug. Int J Androl 1998;21:8-12.

8. Qian SZ, Wang ZG. Gossypol: a potential antifertility agent for males. Annu Rev Pharmacol Toxicol 1984;24:329-60.

9. Yama OE, Osinubi AA, Duru FIO, Noronha CC, Okanlawon AO. The contraceptive effect of methanolic extract of Momordica charantia seed in male sprague Dawley rats. Asian J Pharm Clin Res 2011;4:22-6.

10. Carr TP, Cornelison RM, Illston BJ, Stuefer-Powell CL, Gallaher DD. Plant sterols alter bile metabolism and reduce cholesterol absorption in hamster fed a beef-based diet. Nut Res 2002;22:745-54.

11. Babu PS, Srinivasan K. Hypolipidemic action of curcumin, the active principle of turmeric (Curcuma longa) in streptozotocin induced diabetic rats. Mol Cell Biochem 1997;166:169-75.

12. Bavarva JH, Narasimhacharya AV. Antihyperglycemic and hypolipidemic effects of Costus speciosus in alloxan are induced diabetic rats. Phytother Res 2008;22:620-6.

13. Eliza J, Daisy P, Ignacimuthu S, Duraipandiyan V. Antidiabetic and antilipidemic effect of eremanthin from Costus speciosus (Koen.) Sm., in STZ-induced diabetic rats. Chem Biol Interact 2009;182:67-72.

14. Qin Y, Wu X, Huang W, Gong G, Li D, He Y, Zhao Y. Acute toxicity and subchronic toxicity of steroidal saponins from Dioscorea zingiberensis C. H. Wright in rodents. J Ethnopharmacol 2009;126:543-50.

15. Qian SZ, Wang ZG. Gossypol: a potential antifertility agent for males. Annu Rev Pharmacol Toxicol 1984;24:329-60.

16. Adedapo AA, Omoloye OA, Ohore OG. Studies on the toxicity of an aqueous extract of the leaves of Abrus precatorius in rats. Onderstepoort. J Vet 2007;74:31-6.

17. Chauhan A, Agarwal M. Reversible changes in the antifertility induced by Aegle marmelos in male albino rats. Syst Biol Reprod Med 2008;54:240-6.

18. Shkukani H, Salhab A, Disi A, Shomaf M, Al Quadan F. Antifertility effect of ethanolic extract of Juniperus phoenica (L) in male albino rats. J Herb Pharmacother 2007;7:179-89.

19. Parveen S, Das S, Kundra CP, Pereira BM. A comprehensive evaluation of the reproductive toxicity of Quassia amara in male rats. Reprod Toxicol 2003;17:45-50.

20. Singh K, Gupta RS. Antifertility activity of $\beta$-sitosterol isolated from Barleria prionitis (1.) roots in male albino rats. Int J Pharm Pharm Sci 2016;8:88-96.

21. Tatli-çankaya I, Alqasoumi SI, Abdel-rahman RF, Yusufoglu $\mathrm{H}$ Anul SA, Akaydin G, et al. Evaluating the antifertility potential of the ethanolic extracts of Bupleurum sulphureum and Cichorium intybus in male rats. Asian J Pharm Clin Res 2014;7:211-8.

\section{How to cite this article}

- Ika Puspita Sari, Arief Nurrochmad. SUB-acute toxicity study of an ethanolic extract of pacing (Costus speciosus) in male mice. Int J Pharm Pharm Sci 2016;8(12):97-101. 